\title{
Detection of the CD18 gene mutation as a marker of BLAD genetic disorder of Holstein-Friesian cattle in West Java
}

\author{
Mukh Fajar Nasrulloh, Ari Sulistyo Wulandari, Indriawati, Endang Tri Margawati, Slamet Diah \\ Volkandari *
}

Research Center for Biotechnology, Indonesian Institute of Sciences, Bogor, 16911

*Correspondence: volkandari@gmail.com

(Author contributions: Mukh Fajar Nasrulloh and Slamet Diah Volkandari are the main contributors; Ari

Sulistyo Wulandari, Indriawati, and Endang Tri Margawati are as member contributors in this work)

Received: Received: January 7th, 2020; Accepted: April 6 ${ }^{\text {th }}, 2020$; Published online: July 17th 2020

Abstrak

Tujuan: Bovine Leukocyte Adhesion Deficiency (BLAD) adalah kelainan genetik pada sapi Friesian Holstein $(\mathrm{FH})$ yang dapat menimbulkan dampak ekonomi secara signifikan terhadap pembibitan sapi perah. Mutasi c.383A>G pada gen Cluster of Differentiation Molecule 18 (CD18) diketahui berkaitan dengan BLAD. Penelitian ini bertujuan mendeteksi mutasi gen CD18 yang menyebabkan BLAD pada sapi FH di Provinsi Jawa Barat.

Metode: Genom DNA diekstraksi dari 88 sampel darah sapi FH yang diambil dari Cibungbulang Bogor $(n=34)$, Ciampea - Bogor $(n=31)$, dan Sukabumi $(n=23)$ dengan kit ekstraksi DNA GB300, Geneaid $^{\mathrm{TM}}$. Mutasi gen CD18 dideteksi dengan analisis PCR-RFLP menggunakan enzim restriksi endonuklease TaqI.

Hasil: Semua sampel pada penelitian ini menghasilkan dua fragmen DNA, yaitu 359 bp dan 260 bp dengan genotipe homozigot monomorfik (BB). Sapi FH dengan genotipe BB diindikasikan sebagai sapi normal dan tidak membawa BLAD.

Kesimpulan: Semua sampel sapi FH pada tiga populasi di Jawa Barat bebas dari kelainan genetik BLAD. Identifikasi BLAD pada sapi FH di tempat lain termasuk sapi pejantan di Pusat Produksi Semen di Indonesia diperlukan untuk mencegah penyebaran gangguan genetik ini.

Kata Kunci: BLAD; Kelainan genetik; Gen CD18; Sapi FH; Mutasi; Jawa Barat

Abstract

Objective: Bovine Leukocyte Adhesion Deficiency (BLAD) is a genetic disorder in Holstein-Friesian (HF) cattle that have a significant economic impact on dairy cattle breeding. Mutation c.383A>G in Cluster of Differentiation Molecule 18 (CD18) gene was known as related to BLAD. This study aimed to detect the CD18 gene mutation that causes BLAD of HF cattle in the West Java Province.

Methods: The genomic DNA was extracted from 88 blood samples of HF cattle from Cibungbulang-Bogor $(n=34)$, Ciampea-Bogor $(n=31)$, and Sukabumi $(n=23)$ by the GB300 DNA extraction kit, Geneaid ${ }^{\mathrm{TM}}$. The CD18 gene mutation was detected by PCR-RFLP analysis using the TaqI restriction endonuclease. 
Results: All samples in this study produced two fragments DNA, i.e., 359 bp and 260 bp with the monomorphic homozygote genotype (BB). HF cattle with BB genotype indicated as normal cattle and did not carry BLAD.

Conclusions: All samples in the three populations of West Java were free of BLAD genetic disorder. Identification of BLAD on HF cattle in other places, including bulls in the Center of Semen Production in Indonesia was needed to prevent this genetic disorder.

Keywords: BLAD; Genetic disorder; CD18 gene; HF cattle; Mutation; West Java

\section{INTRODUCTION}

Bovine Leukocyte Adhesion Deficiency (BLAD) genetic disorder was discovered the first time in 1980 in North America and then spread to Europe, East Asia, and South Asia [1]. For the first time, BLAD was brought by Osborndale Ivanhoe bulls and then passed on to his offspring, Penstate Ivanhoe Star. It was passed again to his offspring, Carlin-M Ivanhoe Bell. Carlin-M Ivanhoe Bell was used as a superior male for HF cattle that are spread almost across the country through artificial insemination [2]. Since that time, BLAD has only attacked HF cattle and no studies have reported in other breeds [3, 4].

BLAD or granulocytopathy syndrome is a genetic disorder in Holstein-Friesian (HF) cattle and their offspring because of the autosomal recessive genes. A genetic mutation in exon 2 at the nucleotide position 383 of the Cluster of Differentiation Molecule 18 (CD18) gene affects a substitution from Adenine to Guanine, which is converting Aspartic to Glycine amino acid at the polypeptide position 128 (D128G) [5]. The mutation caused heterodimer integrin $\beta 2$ molecules unexpressed on the neutrophil surface. The $\beta 2$ integrin is an adhesion molecule that plays an important role in the mechanism of neutrophil diapedesis through vascular endothelial to attack infectious agents in the tissues [6]. Consequently, BLAD animals suffer from frequent and recurrent bacterial infections, increased susceptibility to pathogens, delayed wound healing, poor body condition, and fatal illness-causing premature death of affected animals. Thus, the infected calves seldom reached adulthood, and this condition has a bad economic impact on dairy farming [7].

The population of HF cattle in Indonesia has reached 550,141 heads in 2018 and 119,349 heads $(21,7 \%)$ spread in West Java [8]. Bogor and Sukabumi are the districts in West Java that have a high population of HF cattle, i.e. 7,000 heads and 3,900 heads, respectively [9].

The frequency of HF cattle carrying BLAD is quite high in the world. In Indonesia, BLAD presence has already detected in Enrekang (South Sulawesi) and Baturraden (Central Java) [10, 11]. This study aimed to detect CD18 gene mutation that causes BLAD of HF cattle in the West Java province. Identification of BLAD on HF cattle in other places is an important step to prevent this genetic disorder.

\section{MATERIALS AND METHODS}

\section{Samples and DNA extraction}

Samples were obtained from 88 head of HF cattle from different farms in West Java, such as Kunak (Cibungbulang-Bogor) $(\mathrm{n}=34)$, Tegalwaru (Ciampea-Bogor) $(\mathrm{n}=31)$, and Sukabumi $(n=23)$. Three milliliters of blood samples were taken from a jugular vein and collected at a vacutainer tube containing an anticoagulant (K3-EDTA). The genomic DNA was extracted using DNA Isolation Kit

Table 1. Primer sequences, position, and the expected product sizes

\begin{tabular}{lcccc}
\hline $\begin{array}{c}\text { Genetic } \\
\text { Defect }\end{array}$ & Primer Sequence 5'to 3' & Position & $\begin{array}{c}\text { Expected } \\
\text { Product Size }\end{array}$ & Reference \\
\hline \multirow{2}{*}{ BLAD } & BLAD-F: GCTTAGCAGCTGGTGGTAGAG & $831-859$ & & [15] \\
& BLAD-R: CCGTGAGCCTCTTACCAGAGA & $1437-1460$ & & \\
\hline
\end{tabular}




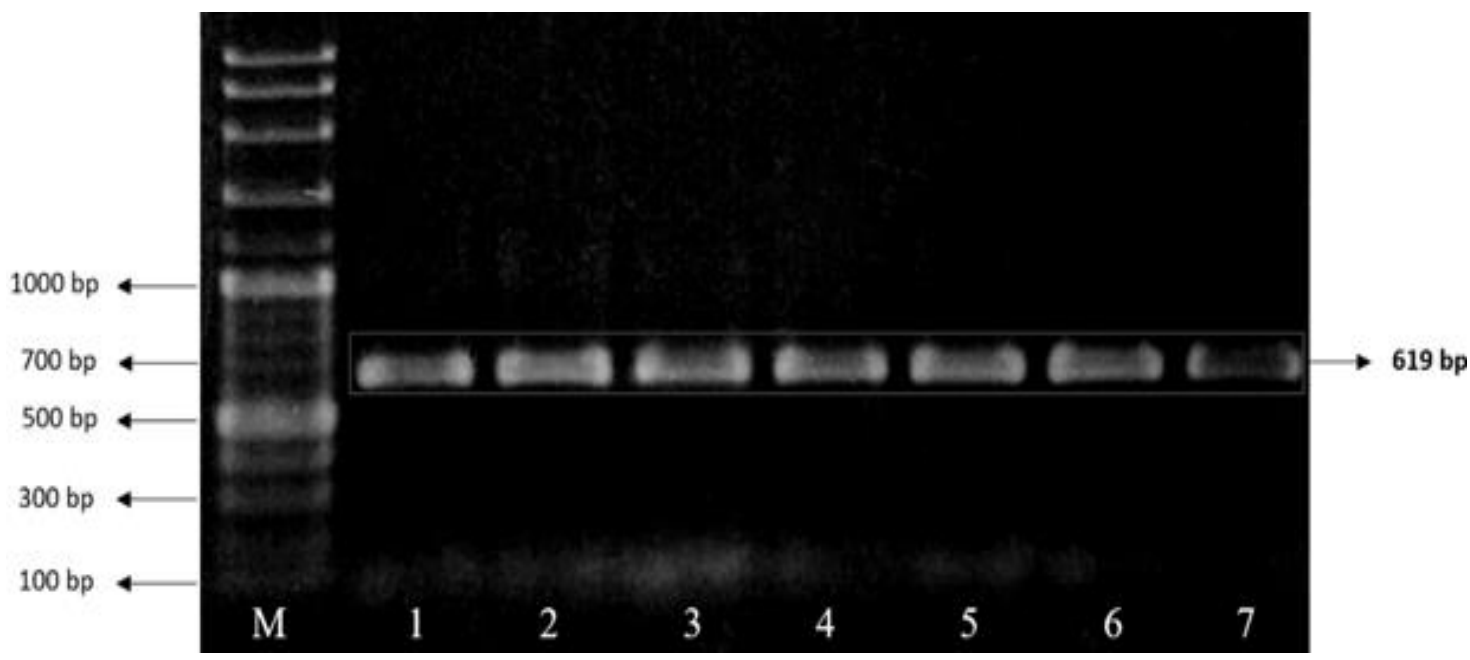

Figure 1. Visualization of PCR product (619 bp). M, DNA ladder $100 \mathrm{bp} ; 1-7$, PCR product

(GB300 DNA extraction kit, Geneaid ${ }^{\mathrm{TM}}$, Taiwan). DNA was then stored at $-20{ }^{\circ} \mathrm{C}$ for the next analysis.

\section{Detection of CD18 gene mutation}

Detection of BLAD used Polymerase Chain Reaction-Restriction Fragment Length Polymorphism (PCR-RFLP) method. Amplification used a pair primer (Table 1) and primer was constructed based on GenBank Accession Number Y12672. DNA target sequence was amplified by the PCR technique using the Thermalcycler (Eppendorf) machine.

The amplifications were carried out in 10 $\mu \mathrm{L}$ reactions containing $1 \mu \mathrm{L}$ of DNA template (consisting of 50-100 ng/ $\mu \mathrm{L}$ DNA), 1 $\mu \mathrm{L}$ of $10 \mathrm{pmol} / \mu \mathrm{L}$ of each primers (BLAD-F and BLAD-R), $5 \mu \mathrm{L}$ of PCR Mastermix (My Taq $^{\mathrm{TM}}$ Red Mix-Bioline), and $2 \mu \mathrm{L}$ of water-free nuclease. PCR process was performed following condition: $94^{\circ} \mathrm{C}$ for 3 min, 35 cycles of $94^{\circ} \mathrm{C}$ for $1 \mathrm{~min}, 58.9^{\circ} \mathrm{C}$ for 1 $\min , 72^{\circ} \mathrm{C}$ for $2 \mathrm{~min}$ and final elongation $72^{\circ} \mathrm{C}$ for $10 \mathrm{~min}$. Amplicons were run on $1 \%$ agarose gel using Biorad PAC 300 electrophoresis machine on 80 Volt for 1 hour. The gel was stained using EtBr for 1 hour and visualized using UV transilluminator.

Identification of BLAD carriers was performed by digestion of the amplified products with TaqI (TC^GA) restriction endonucleases (Product by Thermoscientific ${ }^{\mathrm{TM}}$ ). A total of $3 \mu \mathrm{L}$ PCR products were digested with $0.5 \mu \mathrm{L}$ of the 5 units TaqI enzyme and then incubated at $65^{\circ} \mathrm{C}$ for 3 hours and visualized on $2 \%$ agarose gel. It was electrophoresed on 100 Volt for 1 hour and visualized with UV Transilluminator.

\section{Data analysis}

Data analysis was performed by grouping the restriction electrophoresis results into dominant homozygotes/normal (BB),

Table 2. The genotyping BLAD of HF cattle in this study

\begin{tabular}{|c|c|c|c|c|c|c|}
\hline \multirow{4}{*}{ Regions } & \multirow{4}{*}{$\mathrm{N}$} & \multicolumn{5}{|c|}{ Frequency of } \\
\hline & & \multicolumn{3}{|c|}{ Genotype } & \multicolumn{2}{|c|}{ Allele } \\
\hline & & $\mathrm{BB}$ & $\mathrm{Bb}$ & $\mathrm{bb}$ & $\mathrm{p}$ (normal) & q (mutant) \\
\hline & & & & & {$[(2(\mathrm{BB})+(\mathrm{Bb})): 2 \mathrm{~N}]$} & {$[1-p]$} \\
\hline Cibungbulang, & 34 & $34(100 \%)$ & $0(0 \%)$ & $0(0 \%)$ & 1 & 0 \\
\hline \multicolumn{7}{|l|}{ Bogor } \\
\hline Ciampea, Bogor & 31 & $31(100 \%)$ & $0(0 \%)$ & $0(0 \%)$ & 1 & 0 \\
\hline Sukabumi & 23 & $23(100 \%)$ & $0(0 \%)$ & $0(0 \%)$ & 1 & 0 \\
\hline Total & 88 & $88(100 \%)$ & $0(0 \%)$ & $0(0 \%)$ & 1 & 0 \\
\hline
\end{tabular}




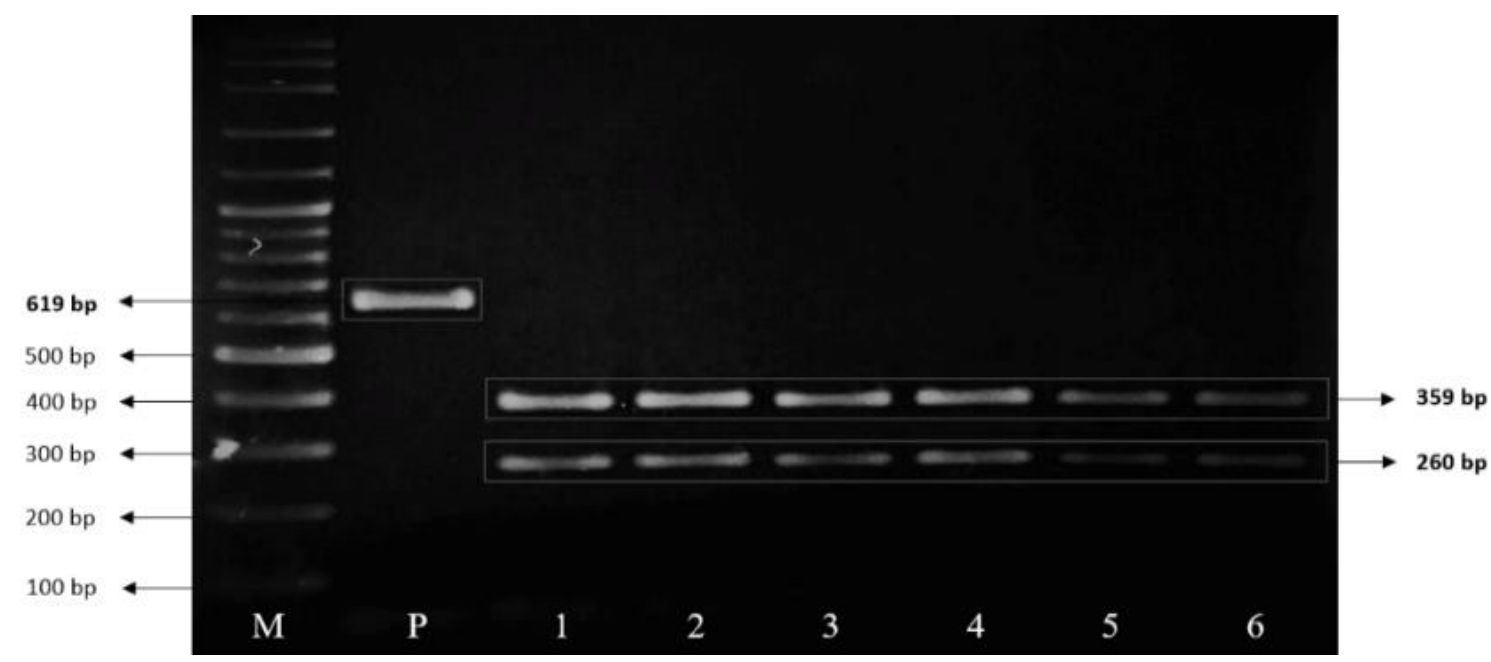

Figure 2. The result of electrophoresis CD18 gene digestion by the TaqI. M, DNA ladder 100 bp; P, PCR product; 1-6, BB genotype of HF cattle

heterozygotes/carrier $(\mathrm{Bb})$, or recessive homozygotes/mutant (bb) that viewed based on the number and size of bands. The determination of mutant allele frequencies is based on the Hardy-Weinberg equation bellow [12]:

$$
p=\frac{2(B B)+(B b)}{2 N} ; q=1-p
$$

Note:

$\mathrm{p}=$ normal allele frequency

$q=$ mutant allele frequency

$\mathrm{BB}=$ number of normal cattle

$\mathrm{Bb}=$ number of the carrier

$\mathrm{bb}=$ number of mutant cattle

$\mathrm{N}=$ number of all samples

Furthermore, the data was presented by descriptive analysis.

\section{RESULTS}

In total, $88 \mathrm{HF}$ cattle samples from Kunak (Cibungbulang - Bogor), Tegalwaru (Ciampea - Bogor), and Sukabumi were successfully amplified using the PCR method. The amplicon of all samples was obtained an appropriate size in the form of a single band measuring $619 \mathrm{bp}$ (Fig. 1) and digested with the TaqI enzyme (Fig. 2) for genotype analysis. Mutation of the CD18 gene was detected using TaqI restriction enzyme (TC^ $\left.{ }^{\wedge} \mathrm{G}\right)$. Based on the restricted prediction, there are three patterns of genotypes i.e. $\mathrm{BB}, \mathrm{Bb}$, and $\mathrm{bb}$. The $\mathrm{BB}$ genotype was showed with two digested fragments, $359 \mathrm{bp}$ and $260 \mathrm{bp}$, while the $\mathrm{Bb}$ genotype was produced with 3 fragments $(619,359$, and $260 \mathrm{bp})$. Then, the bb genotype was performed 1 fragment $619 \mathrm{bp}$, in which the TaqI enzyme could not recognize the mutation point. The result of genotype analysis in this study showed that all of the samples have BB genotype (Table 2).

Table 3. Frequency of BLAD carrier cases among

\begin{tabular}{lcc}
\multicolumn{3}{c}{ HF cattle in different countries } \\
\hline Country & $\begin{array}{c}\text { Frequency } \\
\text { of Carrier }\end{array}$ & References \\
\hline USA & $23 \%$ & {$[6]$} \\
& $13 \%$ & {$[19]$} \\
& $11.3 \%$ & {$[20]$} \\
Taiwan & $9 \%$ & {$[21]$} \\
Poland & $5.8 \%$ & {$[22]$} \\
Czech & $4.8 \%$ & {$[23]$} \\
France & $7.9 \%$ & {$[3]$} \\
Germany & $10 \%$ & {$[24]$} \\
Argentina & $13.5 \%$ & {$[25]$} \\
Japan & $2.88 \%$ & {$[26]$} \\
Brazil & $16-17 \%$ & {$[27]$} \\
Iran & $5.7 \%$ & {$[28]$} \\
India & $3.33 \%$ & {$[29]$} \\
Pakistan & $3.23 \%$ & {$[1]$} \\
Indonesia & $1 \%$ & {$[15]$} \\
& $4 \%$ & {$[11]$} \\
\hline & $0.624 \%$ & {$[10]$} \\
\hline
\end{tabular}




\section{DISCUSSION}

The PCR technique followed by RFLP is a reliable assay for genotyping the BLAD because of the ease of use, cost-effective, and only involved basic equipment and reagent. In this process, TaqI endonuclease cuts only the wild type allele (TCGA) while the mutation destroys the recognition site. Thus, the affected animals (homozygous recessive) had one long unrestricted segment because mutation prevents the restriction [13, 14]. The TaqI digested the CD18 gene fragment and produced three genotypes, including one genotype for carrier animal (heterozygote) and two genotypes for the normal animal [15]. The TaqI restriction point was located at base 1,198 with the specific primers (Fig. 3).

The CD18 locus had two alleles ( $B$ and $b$ ) where the $\mathrm{BB}$ genotype was a dominant homozygous allele (normal), the $\mathrm{Bb}$ genotype was the heterozygote allele (carrier), and the $\mathrm{bb}$ genotype was a recessive homozygous allele (mutant) [15]. In this study, all samples produced two DNA fragments of $359 \mathrm{bp}$ and $260 \mathrm{bp}$, so that all samples were categorized of BB genotype (normal homozygotes). The nucleotide point of $383 \mathrm{CD} 18$ gene was not changed from " $A$ " to " $G$ ", which is converted aspartic acid to amino acid glycine [5]. It showed that all samples were not indicated BLAD disorder.
The cattle that born from the sires and maternal grandsire carriers of BLAD have a $25 \%$ chance of having a BB genotype, $50 \%$ a $\mathrm{Bb}$ genotype, and $25 \%$ a bb genotype. The mutant cattle (bb) cannot be found in adulthood due to premature death, whereas heterozygous alleles are recessive, calves can grow to adulthood as careers [16].

In clinically reviewed, cattle with BLAD are not significantly different from healthy cattle [13]. Clinical symptoms of cattle with recessive homozygous BLAD include recurrent pneumonia, persistent neutrophilia, periodontitis, ulcerative and granulomatous stomatitis, and delayed wound healing [4]. The BLAD can cause premature death due to the body's inability to fight pathogenic microbial infections.

BLAD cases in HF cattle were detected in several countries with different frequency i.e. USA, Taiwan, Poland, Czech, France, Germany, Argentina, Japan, Brazil, Iran, India, Pakistan, and Indonesia (Table 3). In Indonesia, BLAD cases were detected by $4 \%$ of the $80 \mathrm{HF}$ cattle in Baturraden and 0.624\% of the $80 \mathrm{HF}$ cattle in Enrekang [10, 11]. In West Java i.e. Cibinong, Lembang, and Pangalengan, BLAD cases have been investigated and no cattle with BLAD or carrier were found in all samples $[17,18]$. The massive spread of BLAD genetic disorder in cattle is caused by the extensive use of elite

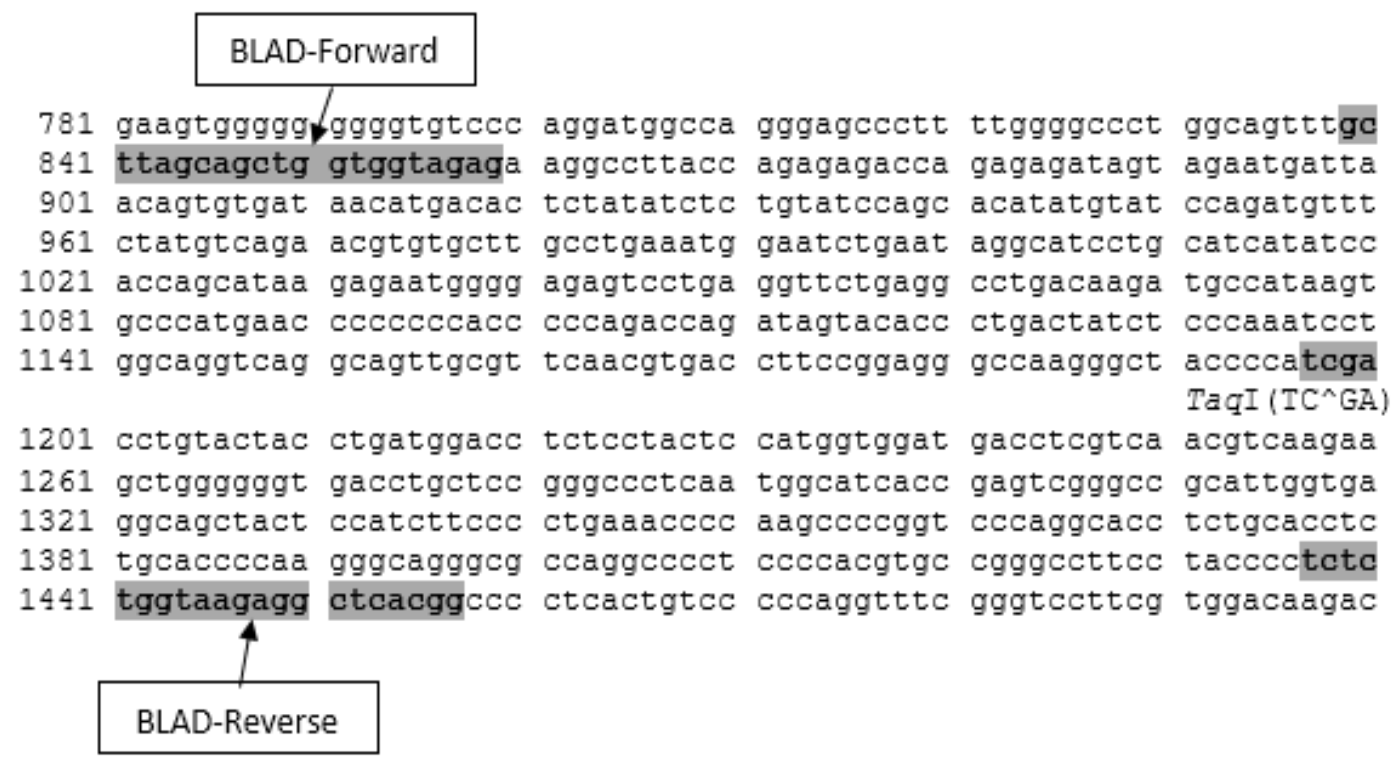

Figure 3. Location of Forward and Reverse Primer of CD18 gene and restricted point using the TaqI enzyme (based on GeneBank Accesion No. Y12672 
sires heterozygous carriers, and this spread is accelerated by artificial insemination programs throughout the world [4].

The case of BLAD in the world, especially in Indonesia must be carefully considered because it can cause an economic loss. Economic losses arising not from a decrease in milk production, but because of the early death of the calf that has a genetic mutation [17]. For example, the dairy farm industry in America loses around US\$ 5 million per year due to that effect [6].

The steps in controlling genetic defects like BLAD are to implementing planned mating patterns and applying good recording management such as establish pedigree records for the animals in a herd [4]. It can be done by visually inspecting pedigrees by developing a simple spreadsheet program, or by using a computerized mating program. Detecting CD18 gene mutation in the sires, especially from breeding centers, and do not use the sires or maternal grandsire carrying BLAD by the artificial insemination or natural mating.

\section{CONCLUSION}

PCR - RFLP is an effective method for detecting genetic mutations that caused BLAD. The population of dairy cattle in Kunak (Cibungbulang-Bogor), Tegalwaru (Ciampea-Bogor), and Sukabumi in West Java Province did not carry BLAD. This result showed that there was no risk yet of BLAD's spread in the three areas, but identification of BLAD on the huge HF cattle population areas is always needed to prevent this genetic disorder.

\section{CONFLICT OF INTEREST}

The authors declare no conflict of interest with any financial organization regarding the material discussed in the manuscript.

\section{ACKNOWLEDGMENTS}

This study was supported by the Laboratory of Animal Genetic Molecular, Research Center for Biotechnology, Indonesian Institute of Sciences (LIPI).

\section{REFERENCES}

1. Patel R.K., K.M. Singh, K.J. Soni, J.B. Chauhan, and K.R. Sambasiva Rao. 2007. Low incidence of bovine leukocyte adhesion deficiency (BLAD) carriers in Indian cattle and buffalo breeds. J. Appl. Genet. 48:153-155. doi:10.1007/BF03194673.

2. Olson A. 2002. New genes: Good and bad. In: U.o.F. Department of Animal Sciences (Ed.), USA.

3. Čítek J., V. Rehout, J. Hajkova, and J. Pavkova. 2018. Monitoring of the genetic health of cattle in the Czech Republic. Veterinární Medicína. 51:333-339.

4. Kumar, V. and A.,\Sharma. 2009. Bovine leukocyte adhesion deficiency syndrome (blad): a recessive disorder in holstein friesian cattle-a review. Agricultural reviews. 30:293-300.

5. Farajallah, A., C. Sumantri, and W. N. Muttaqin. 2007. Identifikasi alel pembawa bovine leucocyte adhesion deficiency (BLAD) pada sapi perah friesian holstein di Indonesia. Pros. Sem. Nas. Tek. Per. Vet. p. 21-25.

6. Shuster D. E., M. E. Kehrli, M. R. Ackermann, and R. O. Gilbert. 1992. Identification and prevalence of a genetic defect that causes leukocyte adhesion deficiency in Holstein cattle. Proc. Natl. Acad. Sci. USA. 89:9225-9229.

7. Nagahata, H. 2004. Bovine leukocyte adhesion deficiency (BLAD): a review. J. Vet. Med. Sci. 66:475-482. doi:10.1292/jvms.66.1475.

8. MoA. 2018. Livestock and animal health statistics 2018. In: D.G.o.L.a.A. Health (Ed.) Ministry of Agriculture Republic of Indonesia, Jakarta.

9. Juwianto, T., E. Mahpudin, A. Panus, A. Rahmawan, and Sodirun. 2018. Investigasi outbreak suspek bovine tuberculosis (btb) pada sapi perah di peternakan $x$ di 
Kabupaten Bogor tahun 2018. The 20th FAVA CONGRESS \& The 15th KIVNAS PDHI. p. 474-477.

10. Dagong, M. I. A., L. Rahim, R. R. S. R. A. Bugiwati, and Nurmulyaningsih. 2018. Allele frequency estimation of BLAD (Bovine Leukocyte Adhesion Deficiency) in dairy cattle in Enrekang Regency South Sulawesi Indonesia. 1st Intl. Conf. Food. Agri. p. 1-5. doi:10.1088/1755-1315/207/1/012031.

11. Muttaqin, W. N. 2007. Frekuensi alel subunit CD18 Sapi Friesian-Holstein (FH) pada peternakan di Lembang, Baturraden dan wilayah Jabotabek. Fakultas Matematika dan Ilmu Pengetahuan Alam, IPB University, Bogor.

12. Andrews C. 2010. The Hardy-Weinberg Principle [Internet]. [cited 2020 Apr 17]. Available from: https://www.nature.com/ scitable/knowledge/library/the-hardy-wei nberg-principle-13235724/.

13. Adamov, N., M. Dine, I. Esmerov, and P. Dovc. 2014. Detection of recessive mutations (BLAD and CVM) in Holstein-Friesian cattle population in Republic of Macedonia. Maced. Vet. Rev. 37:61-68.

doi:10.14432/j.macvetrev.2013.11.005.

14. Zhang, Y., X. Fan, D. Sun, Y. Wang, Y. Yu, Y. Xie, S. Zhang, and Y. Zhang. 2012. A novel method for rapid and reliable detection of complex vertebral malformation and bovine leukocyte adhesion deficiency in Holstein cattle. J. Anim. Sci. Biotechnol. 3:24.

15. Nasreen, F., N. A. Malik, M. N. Riaz, and J. A. Qureshi. 2009. Detection and screening of bovine leukocyte adhesion deficiency in Pakistan using molecular methods. Hereditas. 146:74-78.

doi:10.1186/2049-1891-3-24.
16. Perkins, K. H., M. J. VandeHaar, R. J. Tempelman, and J. L. Burton. 2001. Negative energy balance does not decrease expression of leukocyte adhesion or antigen-presenting molecules in cattle. J. Dairy Sci. 84:421-428. doi:10.1186/2049-1891-3-24.

17. Herodita, L. U. 2009. Identifikasi Bovine leukococyte adhesion deficiency (BLAD) pada Peternakan sapi perah Friesien-Holstein di Jawa dan Bali. Fakultas Peternakan, IPB University, Bogor.

18. Indriawati, M. Ridwan, and E. T. Margawati. 2016. Identifikasi penyakit bovine leukocyte adhesion deficiency (BLAD) pada sapi perah Friesian Holstein menggunakan metode molekuler. Pros. Sem. Nas. Kebangkitan. Pet. II. p.858-863.

19. Patel, M., R. Patel, K. Singh, D. Rank, M. Thakur, and A. Khan. 2011. Detection of genetic polymorphism in CD18 gene in cattle by PCR-RFLP. Russ. J. Gen. 41:1697-1701.

20. Norouzy, A., M. R. Nassiry, F. Eftekhari Shahrody, A. Javadmanesh, M.R. Mohammad Abadi, and G.E. Sulimova. 2005. Identification of bovine leucocyte adhesion deficiency (BLAD) carriers in Holstein and Brown Swiss AI bulls in Iran. Genetika. 41:1697-701. doi:10.1007/s11177-006-0014-7.

21. Akyüz, B., O. Ertuğrul, and Ö. K. Ağaoğlu. 2010. Detection of bovine leukocyte adhesion deficiency (BLAD) allele in Holstein cows reared in Kayseri vicinity. Kafkas. Univ. Vet. Fak. Derg. 16:519-521.

22. Meydan, H., M. A. Yildiz, and J. S. Agerholm. 2010. Screening for bovine leukocyte adhesion deficiency, deficiency of uridine monophosphate synthase, complex vertebral malformation, bovine 
citrullinaemia, and factor XI deficiency in Holstein cows reared in Turkey. Acta. Vet. Scand. 52: 56. doi:10.1186/1751-0147-52-56.

23. Şahin, E., T. Karslı, and A. Galiç, M.S. Balcığlu. 2013. Identification of bovine leukocyte adhesion deficiency (BLAD) and bovine citrullinaemia (BC) alleles in Holstein cows reared in Antalya region. J. App. Anim. Res 41:56-60. doi:10.1080/09712119.2012.738221.

24. AĞAoĞLu, O., A. R. AĞAoĞLu, and M. Saatci. 2015. Estimating allele frequencies of some hereditary diseases in Holstein cattlereared in Burdur Province, Turkey. Turk. J. Vet. Anim. Sci. 39:338-342. doi:10.3906/vet-1412-13.

25. Czarnik, U., G. Grzybowski, S. Kamiński, B. Prusak, and T. Zabolewicz. 2007. Effectiveness of a program aimed at the elimination of BLAD-carrier bulls from Polish Holstein-Friesian cattle. J. Appl. Genet. 48:375-377. doi:10.1007/BF03195235. 